\title{
CONGENITAL THROMBOCYTOPENIC PURPURA
}

\author{
BY \\ PATIENCE E. BARCLAY, M.B., B.S., M.R.C.P., D.C.H. \\ Late Medical Registrar, Hospital for Sick Children, Great Ormond Street, London
}

Congenital thrombocytopenic purpura is a rare condition. A review of the literature fails to show any case reported from this country. In 1925 Rushmore was able to find seven examples of purpura in pregnancy in which both mother and child were affected, but the type of purpura was not specified. Since that time congenital thrombocytopenic purpura has been recorded on fourteen occasions with eight thrombocytopenic mothers (see table 1). The following instance in a newborn infant whose mother did not suffer from the disease may therefore be of interest.

\section{Clinical details}

A male infant, three days old, was admitted to the Hospital for Sick Children, Great Ormond Street, on April 21, 1944, with a purpuric eruption. He was born at term following an uneventful pregnancy and labour. On the second day of life purpuric spots were first noticed on the buttocks and extended rapidly to the legs and scalp. Jaundice also appeared at this time. His parents and one older sister were healthy, but the second sister suffered from recurrent epistaxis.

Examination showed a normally responsive, wellnourished baby, weighing $5 \mathrm{lb} .14 \mathrm{oz}$. T. $100 \cdot 2^{\circ} \mathrm{F}$. (rectal), P. 140, R. 40. A diffuse purpuric rash was present over all areas of the skin and also on the hard palate with small ecchymoses on the back and legs; mild jaundice was present; mucous membranes were a good colour; the spleen was not palpable; and there was no abnormality of heart, lungs, abdomen or central nervous system. No evidence of infection was found. The urine and stools were free from blood. Pathological investigations carried out on the fourth day were as follows:-

INFANT:

Blood count: R.B.C. 6,700,000 per c.mm.; Hb. 130 per cent. (Sahli); C.I. 0.97. W.B.C. $\quad \ldots \quad 13,300$ per c.mm. Polymorph.. 58 per cent. with 38 per cent. stab forms.

$\begin{array}{lr}\text { Lymphocytes } & 37 \text { per cent. } \\ \text { Monocytes } & 1 \text { per cent. } \\ \text { Eosinophils } & 4 \text { per cent. }\end{array}$

Eosinophils 4 per cent.

No immature cells seen.

\begin{tabular}{|c|c|c|c|}
\hline \multirow{2}{*}{\multicolumn{2}{|c|}{ Platelet count }} & 8 & \\
\hline & & .. & 6000 per c.mm. \\
\hline Bleeding time & & .. & $\begin{array}{l}10 \text { minutes (Duke's } \\
\text { method-normal 2- } \\
5 \text { minutes). }\end{array}$ \\
\hline Prothrombir & .. & . & $\begin{array}{l}\text { nds (McTookey's } \\
\text { lod-normal 11- } \\
\text { econds). }\end{array}$ \\
\hline Blood & & . & Rh-positive. \\
\hline
\end{tabular}

MOTHER:

Platelet count $\quad . \quad \ldots \quad 350,000$ per c.mm.

Blood Wassermann reaction negative.

Blood group O $\quad . . \quad \ldots \quad$ Rh-positive.

No abnormal antibodies were present in the serum.

The infant remained in hospital for four weeks, during which time he made good progress, gaining $20 \mathrm{oz}$. in weight. The purpura faded gradually; a few new lesions appeared during the first fortnight; the stools contained streaks of bright blood from time to time and there was one small haematemesis. He was symptom free by the end of the third week. Apart from a temperature of $100^{\circ} \mathrm{F}$. on admission he was afebrile, his rectal temperature varying between $97.6^{\circ} \mathrm{F}$. and $99^{\circ} \mathrm{F}$. for the first eight days and then becoming stabilized at $98^{\circ} \mathrm{F}$. No infection was detected at any time. The jaundice continued for eighteen days which is considerably longer than usual in physiological jaundice; the fall in the red blood count was also marked (see table 2). In spite of clinical improvement the thrombocytopenia persisted with a platelet count of only 10,000 per c.mm. on discharge from hospital at one month old (see table 2). The normal figures for the neonatal period are 200,000-300,000 per c.mm. (Sanford, 1942).

The patient was not seen again until he was six months old because of the danger from flyingbombs in the London area. During the interval he had remained symptom free although he had had a severe attack of bronchitis. The platelets had risen to 350,000 per c.mm. and the bleeding time had fallen to $5 \frac{1}{2}$ minutes.

This was a spontaneous recovery. The only treatment the child received was vitamin $\mathrm{K}(5 \mathrm{mgm}$. kapilon intramuscularly) on admission and liver (Armour's Proethron forte $2 \mathrm{c.cm}$.) given on the twenty-first and twenty-third days, the latter being without effect on the thrombocytes. Owing to the benign clinical course blood transfusion was not considered necessary.

\section{Comment}

This appears to be an undoubted example of congenital thrombocytopenic purpura. The rash was noticed by the second day and the platelets were reduced to 6,000 per c.mm. on the fourth day. A symptomatic purpura was unlikely as no infection was found, no drug liable to cause a thrombocytopenia had been given to mother or child, and in spite of the prolonged jaundice no other blood disease was demonstrable.

In nine of the cases reviewed the condition was 
TABLE 1.-CASES OF CONGENITAL THROMBOCYTOPENIC PURPURA

\begin{tabular}{|c|c|c|c|c|c|c|}
\hline Reference & Manifestations & $\begin{array}{l}\text { Platelet } \\
\text { count per } \\
\text { c.mm. }\end{array}$ & $\begin{array}{c}\text { Bleeding } \\
\text { time } \\
\text { (minutes) }\end{array}$ & Treatment & Course & Family \\
\hline $\begin{array}{l}\text { WALTNER } \\
(1924)\end{array}$ & $\begin{array}{l}\text { Purpura of skin } \\
\text { at birth. }\end{array}$ & 90,000 & 12 & None. & $\begin{array}{l}\text { Marked icterus; some } \\
\text { sepsis. Symptom } \\
\text { free by seven } \\
\text { months. }\end{array}$ & $\begin{array}{l}\text { Mother: purpura at } \\
\text { seventh month of } \\
\text { pregnancy. Plate- } \\
\text { lets } 50,000 \text {. Bleed- } \\
\text { ing time } 27 \text { minutes. }\end{array}$ \\
\hline $\begin{array}{l}\text { LESCHKE } \\
(1926)\end{array}$ & $\begin{array}{l}\text { Purpura of skin } \\
\text { at birth with } \\
\text { haematuria and } \\
\text { melaena. }\end{array}$ & 0 & $12-15$ & None. & $\begin{array}{l}\text { No bleeding after } \\
\text { tenth day. }\end{array}$ & $\begin{array}{l}\text { Mother: purpura at } \\
\text { fifth month of preg- } \\
\text { nancy. } \\
60,000 \text {. }\end{array}$ \\
\hline $\begin{array}{l}\text { LIEBLING } \\
\text { (1926) }\end{array}$ & $\begin{array}{l}\text { Purpura of skin } \\
\text { at birth with } \\
\text { haematemesis } \\
\text { and melaena. }\end{array}$ & 40,000 & - & $\begin{array}{l}\mathrm{H} \text { a e m o p la st i n, } \\
5 \text { c.cm. intra- } \\
\text { muscularly. }\end{array}$ & $\begin{array}{l}\text { Did well. Purpura } \\
\text { faded at one month. } \\
\text { Platelets } 240,000 \text {. }\end{array}$ & $\begin{array}{l}\text { Mother: purpura at } \\
\text { fifth month of preg- } \\
\text { nancy. Platelets } \\
40,000 \text {. }\end{array}$ \\
\hline $\begin{array}{l}\text { GREEN- } \\
\text { WALD } \\
\text { (1929) }\end{array}$ & $\begin{array}{cc}\text { Purpura of } & \text { skin } \\
\text { appeared } & \text { on } \\
\text { fifth day. } & \end{array}$ & 30,000 & 5 & None. & $\begin{array}{l}\text { Died on seventh day. } \\
\text { Congenital morbus } \\
\text { cordis. Thrombo- } \\
\text { cytes scanty and } \\
\text { abnormal in appear- } \\
\text { ance. }\end{array}$ & - \\
\hline $\begin{array}{l}\text { BAYER } \\
\quad(1931)\end{array}$ & $\begin{array}{l}\text { Purpura of skin } \\
\text { at birth. }\end{array}$ & 50,000 & 40 & None. & $\begin{array}{l}\text { No fresh bleeding } \\
\text { after birth. Plate- } \\
\text { lets } 320,000 \text { by } \\
\text { second year. }\end{array}$ & - \\
\hline Ibid. & $\begin{array}{l}\text { Purpura of skin } \\
\text { at birth. }\end{array}$ & 48,000 & $6 \frac{1}{2}$ & None. & $\begin{array}{l}\text { No fresh bleeding } \\
\text { after birth. Plate- } \\
\text { lets } 150,000 \text { on fifth } \\
\text { day. }\end{array}$ & $\begin{array}{l}\text { Twin. Platelets } \\
77,000 . \quad \text { Bleeding } \\
\text { time } 1 \text { minute. No } \\
\text { symptoms. }\end{array}$ \\
\hline Ibid. & $\begin{array}{l}\text { Purpura of skin } \\
\text { and mucous } \\
\text { membranes at } \\
\text { birth c with } \\
\text { haematemesis } \\
\text { and melaena. }\end{array}$ & 45,000 & 11 & $\begin{array}{l}\text { Coagulen and gela- } \\
\text { tin intramuscularly. }\end{array}$ & $\begin{array}{l}\text { No fresh bleeding } \\
\text { after fifth day. Plate- } \\
\text { lets } 280,000 \text { by } \\
\text { second year. }\end{array}$ & - \\
\hline Ibid. & $\begin{array}{l}\text { Purpura of skin } \\
\text { at birth. Hae- } \\
\text { matemesis on } \\
\text { second day. }\end{array}$ & 50,000 & 90 & None. & $\begin{array}{l}\text { Died on second day. } \\
\text { Widespread pur- } \\
\text { puric lesions. }\end{array}$ & 一 \\
\hline $\begin{array}{l}\text { GUTT- } \\
\text { FREUND } \\
\text { (1933) }\end{array}$ & $\begin{array}{l}\text { Purpura of skin } \\
\text { and muc ou s } \\
\text { membranes at } \\
\text { birth. }\end{array}$ & 0 & 40 & $\begin{array}{l}90 \mathrm{c.cm} \text {. blood intra- } \\
\text { muscularly, also } \\
\text { blood transfusion } \\
(? \text { amount }) .\end{array}$ & $\begin{array}{l}\text { Continued to bleed. } \\
\text { Died of pneumonia } \\
\text { at four months. }\end{array}$ & $\begin{array}{l}\text { Father: severe epis- } \\
\text { taxis and excessive } \\
\text { bruising. Mother: } \\
\text { Platelets } 32,000 \text {, but } \\
\text { symptom free. }\end{array}$ \\
\hline $\begin{array}{l}\text { SANFORD } \\
(1936)\end{array}$ & $\begin{array}{l}\text { Purpura of skin } \\
\text { at birth. }\end{array}$ & 20,000 & - & None. & $\begin{array}{l}\text { No fresh lesions after } \\
\text { birth. Platelets } \\
137,000 \text { by tenth } \\
\text { day. Mother and } \\
\text { child both showed } \\
\text { increased disinte- } \\
\text { grating power of } \\
\text { platelets. }\end{array}$ & $\begin{array}{cc}\text { Mother: } & \text { recurrent } \\
\text { purpura. } & \text { Platelets } \\
17,500 . & \end{array}$ \\
\hline $\begin{array}{l}\text { DAVIDSON } \\
\quad(1937)\end{array}$ & $\begin{array}{l}\text { Purpura of skin } \\
\text { at birth. }\end{array}$ & 56,000 & 3 & $\begin{array}{l}\text { Blood, } 100 \text { c.cm. } \\
\text { intramuscularly } \\
\text { without improve- } \\
\text { ment. Bothrops } \\
\text { antitoxin, } 5 \text { c.cm. } \\
\text { intramuscularly } \\
\text { with clinical re- } \\
\text { covery. }\end{array}$ & $\begin{array}{l}\text { Platelets } 672,000 \text { by } \\
\text { ten we e k s. Re- } \\
\text { mained normal for } \\
\text { two years. }\end{array}$ & $\begin{array}{l}\text { Mother : splen- } \\
\text { ectomy eight years } \\
\text { before for thrombo- } \\
\text { cytopenic purpura. } \\
\text { Platelets } 6,000- \\
50,000 .\end{array}$ \\
\hline $\begin{array}{l}\text { WHITNEY } \\
\text { (1942) }\end{array}$ & $\begin{array}{l}\text { Purpura of skin } \\
\text { at birth. }\end{array}$ & 80,000 & 1 & $\begin{array}{l}\text { Blood intramuscu- } \\
\text { larly, } 20 \text { c.cm. }\end{array}$ & $\begin{array}{l}\text { Died third day. Ten- } \\
\text { torial tear. Wide- } \\
\text { spread purpura. }\end{array}$ & $\begin{array}{l}\text { Mother of these two } \\
\text { infants had splen- } \\
\text { ectomy at fourteen }\end{array}$ \\
\hline Ibid. & $\begin{array}{l}\text { Purpura of skin } \\
\text { at birth. }\end{array}$ & 90,000 & 11 & $\begin{array}{l}\text { Blood intramuscu- } \\
\text { larly, } 55 \text { c.cm., } \\
\text { twice. }\end{array}$ & $\begin{array}{l}\text { Died second day with } \\
\text { multiple haemor- } \\
\text { rhages. }\end{array}$ & $\begin{array}{l}\text { years of age. Plate- } \\
\text { lets } 70,000 \text {. }\end{array}$ \\
\hline $\begin{array}{l}\text { URBANSKY } \\
(1942)\end{array}$ & $\begin{array}{l}\text { Purpura of skin } \\
\text { and mucous } \\
\text { membranes. }\end{array}$ & 23,200 & $5 \frac{1}{4}$ & $\begin{array}{l}50 \mathrm{c.cm} \text {. blood intra- } \\
\text { venously. }\end{array}$ & $\begin{array}{l}\text { Purpura faded in a } \\
\text { few days. Bleeding } \\
\text { time } 1 \frac{1}{2} \text { minutes at } \\
2 \frac{1}{2} \text { years old. }\end{array}$ & $\begin{array}{l}\text { Mother had splen- } \\
\text { ectomy six years } \\
\text { previously for } \\
\text { thrombocytopenic } \\
\text { purpura. Platelets } \\
75,000 \text { at six months } \\
\text { of pregnancy. }\end{array}$ \\
\hline
\end{tabular}


TABLE 2

\begin{tabular}{|c|c|c|c|c|c|}
\hline Date & $\begin{array}{l}\text { Hb. } \\
\text { per cent. }\end{array}$ & $\begin{array}{l}\text { R.B.C. } \\
\text { per c.mm. }\end{array}$ & $\begin{array}{l}\text { W.B.C. } \\
\text { per c.mm. }\end{array}$ & $\begin{array}{l}\text { Platelets } \\
\text { per c.mm. }\end{array}$ & Bleeding time \\
\hline $\begin{array}{r}22.4 .1944 \\
1.5 .1944 \\
8.5 .1944 \\
12.5 .1944 \\
26.5 .1944 \\
24.10 .1944\end{array}$ & $\begin{array}{r}130 \\
80 \\
80 \\
- \\
-\end{array}$ & $\begin{array}{c}6,700,000 \\
3,500,000 \\
4,100,000 \\
- \\
-\end{array}$ & $\begin{array}{c}13,300 \\
22,200 \\
16,000 \\
= \\
=\end{array}$ & $\begin{array}{r}6,000 \\
7,000 \\
15,000 \\
12,000 \\
10,000 \\
350,000\end{array}$ & $\begin{array}{l}10 \text { minutes }+ \\
10 \text { minutes }+ \\
- \\
5 \frac{1}{2} \text { minutes }\end{array}$ \\
\hline
\end{tabular}

familial; in the four collected by Bayer the mothers' platelet counts were not noted. In the present instance the mother's blood was normal and she had never shown a tendency to bleed.

The prognosis in these infants is of some interest. Nine of the fourteen recovered during the first few weeks of life but their progress was not followed further except in three who remained healthy for two years. It would be instructive to know whether or not these children tend to relapse later in life. Five of the infants died, associated lesions may have been the cause of death in three of them. Two only died of uncomplicated purpura. Thus prognosis does not appear to be so grave as might be expected.

From a study of these reports therapy seems to have had little effect. Five infants recovered without treatment. Blood transfusions in adequate amounts would seem to be the rational treatment in any severe case. The advisability of splenectomy at birth was discussed by Whitney (1942) but in view of the above figures does not appear justifiable.

\section{Summary}

A case of congenital thrombocytopenic purpura is reported.

Examples of congenital thrombocytopenic purpura collected from the literature are tabulated.

The prognosis and treatment of the condition is considered.

Thanks are due to Dr. W. G. Wyllie for permission to publish this case.

\section{REFERENCES}

Bayer, W. (1931). Jb. Kinderheilk., 133, 222.

Davidson, L. T. (1937). Amer. J. Dis. Child., 54, 1324.

Greenwald, H. M., and Sherman, I. (1929). Ibid., 38, 1245.

Guttfreund, A. (1933). Mschr. Kinderheilk., 55, 436.

Leschke, E., and Witthower, E. (1925). Z. klin. Med., $102,549$.

Liebling, P. (1926). Amer. J. Obstet. Gynec., 11, 847.

Rushmore, S. (1925). Ibid., 10, 553.

Sanford, H. N., Leslie, E., and Crame, E. (1936). Amer. J. Dis. Child., 51,1114 .

and Shimigelsky, I. (1942). Ibid., 63, 729.

Urbansky, A. X., and Hunter, C. I. (1942). J. Amer. med. Ass., 120, 754-756.

Waltner, K. (1924). Jb. Kinderheilk., 106, 307.

Whitney, L. H., and Barritt, S. B. (1942). Amer. J. Dis. Child., 64, 705. 